\title{
GEOGRAPHIC VARIATION AND INTERGRADATION IN THE ELEGANT QUAIL
}

\author{
DIEGO C. BLANCO, DEVON A. DERAAD, and JAMES M. MALEY, Moore \\ Laboratory of Zoology, Occidental College, 1600 Campus Road, Los Angeles, \\ California 90041; dblanco085@gmail.com
}

\begin{abstract}
The Elegant Quail (Callipepla douglasii) is restricted to western mainland Mexico from Sonora south to Jalisco. It comprises five subspecies, described primarily on the basis of differences in plumage color and patterns. To assess patterns of differentiation in the Elegant Quail, we examined 114 specimens representing these five subspecies in the Moore Laboratory of Zoology. We measured wing chord, tail length, exposed culmen, and tarsus length, finding that males were significantly larger than females but that the only significant size difference between subspecies was that nominate douglasii has a tail longer than in the other four. Thus size is a minor component of the Elegant Quail's geographic variation in comparison to that in plumage color and pattern. We examined the plumage of specimens from southern Sonora and northern Sinaloa and found that several appeared to be intergrades between $C$. $d$. douglasii and $C . d$. bensoni and between $C . d$. bensoni and $C$. $d$. languens.
\end{abstract}

The purpose of our research into the five subspecies of the Elegant Quail listed by Dickinson and Remsen (2013) was to examine their morphological differences and to reassess the degree of variation among them. Besides Callipepla douglasii douglasii (originally described as Ortyx douglasii Vigors, 1829 (type locality Mazatlan, Sinaloa\}), the four other subspecies are C. $d$. bensoni (Callipepla elegans bensoni Ridgway, 1887 ["Campos, = 18 miles north of Cumpas, Sonora"] [Friedmann 1946:303]) in the northern end of the bird's range, C. d. teres (Lophortyx d. teres Friedmann, 1943 \{Las Palmas, on the southern outskirts of Puerto Vallarta, northwestern Jalisco\}) and C. d. impedita (L. d. impedita Friedmann, 1943 \{San Blas, Tepic, Nayarit\}) in the central and southern portions of the species' range, and $C$. d. languens (L. d. languens Friedmann, 1943 \{Trompa, 24 km southwest of Moris, Chihuahua\}) on the east slope of the Sierra Madre Occidental in western Chihuahua. Nominate C. $d$. douglasii is known from southern Sonora, Sinaloa, northwestern Durango, and northern Nayarit. Figure 1 shows the species' distribution by subspecies. To identify the characteristics of plumage pattern and coloration typical of each subspecies as described by its author, we used the identification key published by Friedmann (1943) and also referred to Friedmann (1946).

\section{METHODS}

\section{Specimen Selection}

We began the study by selecting 114 specimens ( 71 males and 43 females) from the collection of the Moore Laboratory of Zoology (MLZ) suitable for our analyses. We referenced field notes and information on specimen tags to verify the locality from which each specimen was collected and assessed the quality of each specimen, excluding from our sample damaged specimens and juvenile birds that provided no measurements or plumage characteristics useful for our study. 


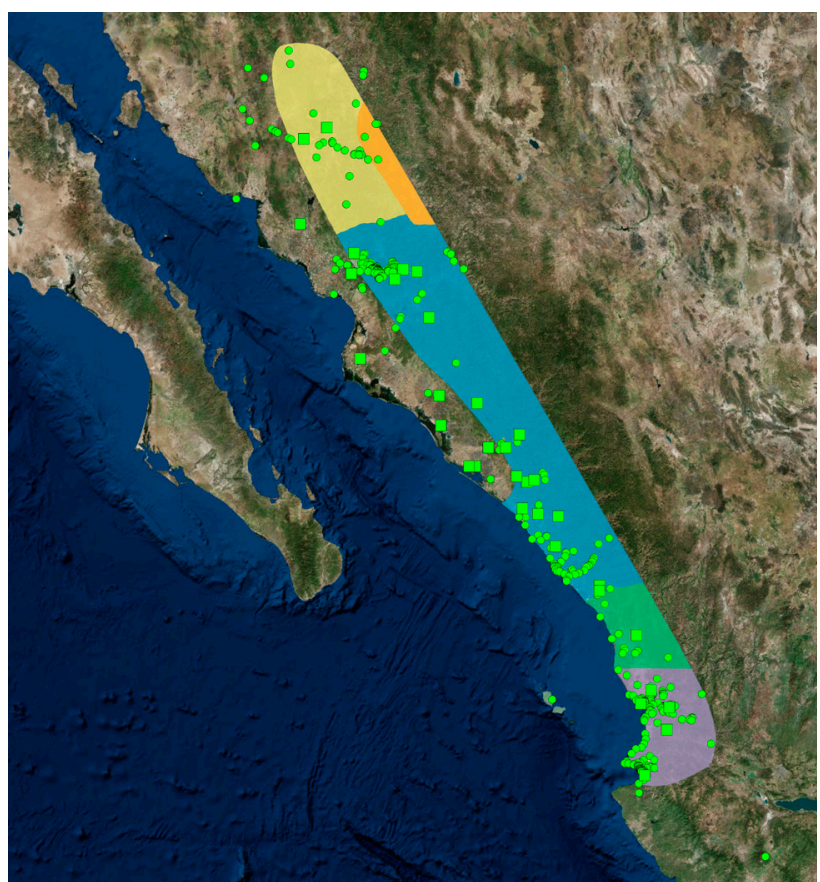

Figure 1. Distribution of the subspecies of the Elegant Quail. Highlighted area, species' range as outlined at www.infonatura.natureserve.org. Yellow, Callipepla douglasii bensoni; orange, $C$. $d$. languens; blue, nominate $C$. d. douglasii; green, C. $d$. impedita; purple, C. $d$. teres. Green squares, localities of specimens used in this study; green circles, sightings reported to www.eBird.org.

\section{External Measurements}

Using digital calipers we measured wing chord from the bend of the wrist to the end of the longest primary, tail length from the attachment of the central rectrices to the end of the longest rectrix, tarsus length from the tibiotarsal joint to the most distal undivided tarsal scute, and culmen length from the base of the exposed culmen to the distal end of the beak. The majority of specimens used in the study were collected and prepared between 1933 and 1954 by Chester C. Lamb by a standard technique, obviating concerns about variability in shrinkage and deformation of the specimens as a result of differences in their preservation. To decrease variability in the data due to measurement errors, before recording the numbers analyzed, we assessed repeatability, measuring each structure we examined multiple times.

\section{Subspecies Identification}

We categorized our sample by three methods, coding douglasii as 1 , bensoni as 2 , teres as 3, impedita as 4 , and languens as 5. First, we recorded each specimen's subspecies as assigned on its tag, as well as its locality, sex, 
and age. Second, we identified each specimen to subspecies by inspection solely on the basis of plumage characteristics as described by Friedmann (1943), regardless of the subspecies as identified on specimen label or the locality of collection. All color terminology follows that used in the Naturalist's Color Guide (Smithe 1975). We identified males on the basis of color of the throat and sides of head, extensiveness of rusty markings on back, and patterns of spots and color on the abdomen (Figure 2). Predominantly black throat feathers, a pale breast, and fewer and duller rusty markings on back were diagnostic of bensoni; predominantly white throat feathers, a darker breast, and extensive bright rusty markings on the back were considered diagnostic of douglasii; extensive rusty markings on the abdomen and primaries not extending beyond the secondaries were considered diagnostic of teres; a dusky-tinged or darker abdomen was considered diagnostic of impedita; and a predominantly white throat along with rusty spotting on the breast were considered diagnostic of languens. For females, we considered crest color, throat streaking, and ventral coloration. A uniformly dark brown or blackish crest and pronounced throat streaking were considered diagnostic for bensoni, a paler crest with dark barring and an almost completely unmarked white throat were considered diagnostic for douglasii, a dark ventral area in

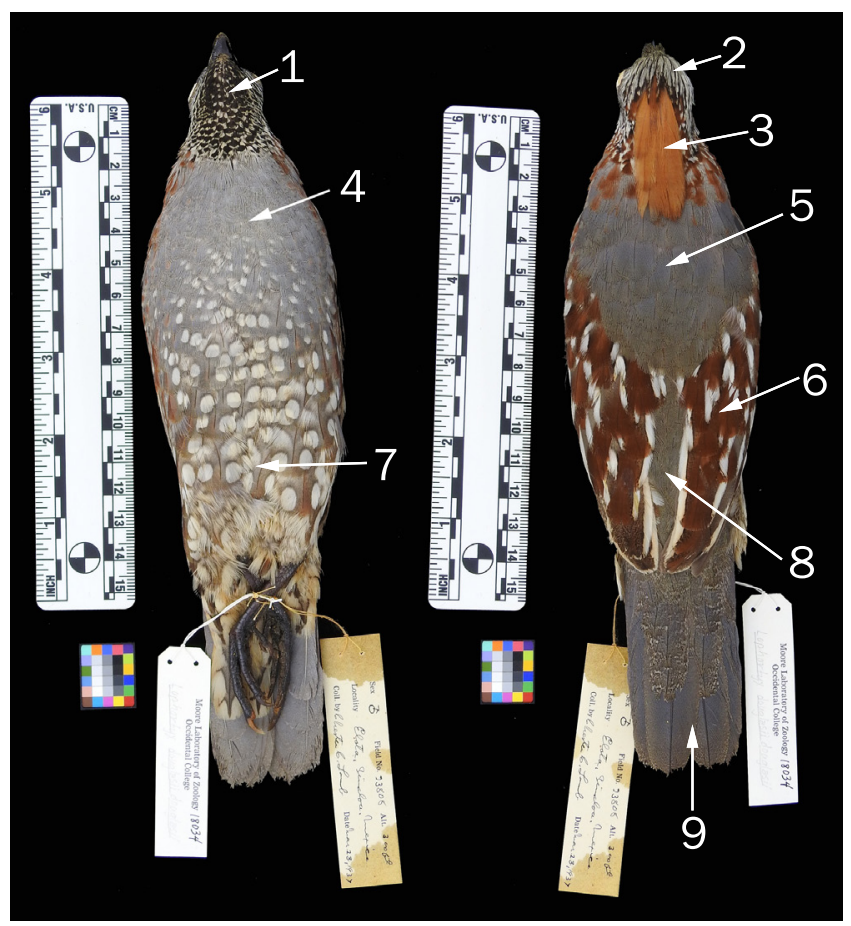

Figure 2. Patches of plumage of a male Elegant Quail (MLZ 18034) referenced in text: 1 , throat; 2 , crown; 3 , crest; 4 , breast; 5 , nape/back; 6 , scapulars/coverts; 7 , ventral area; 8 , rump; 9, tail. 
combination with a visible extension of the primaries beyond the secondaries was considered diagnostic of impedita, and a dark belly in combination with no extension of the primaries beyond the secondaries was considered diagnostic of teres. The female plumage of languens is not known.

Third, we assigned each specimen to subspecies on the basis of geographic range only, as follows: douglasii in southern Sonora, Sinaloa, northwestern Durango, and northern Nayarit; bensoni in northern and central Sonora; teres in northwestern Jalisco; impedita in central and southern Nayarit; and languens in western Chihuahua (Friedmann 1943). The purpose of the independent assessment of plumage characters and geographic location was to investigate how the plumage characters vary throughout the species' range without respect to each subspecies' previously reported range.

\section{Statistical Analysis}

We used the RStudio interface for the statistical coding language " $\mathrm{R}$ " to run multivariate analysis of variance tests (MANOVA) and principal component analyses (PCA) on the measurements. We used MANOVA tests and PCA biplots to confirm the Elegant Quail's significant sexual dimorphism and to interpret whether the subspecies differ significantly in each of the four characteristics we measured. Age classes were not factored into the analysis, as the sample measured intentionally consisted of adult birds exclusively. All analyses and data visualizations are designed to be repeatable in an $\mathrm{R}$ script and are available along with our dataset, open source, at github.com/ DevonDeRaad.

\section{RESULTS}

Our examination of several plumage characters and four structural measurements of Elegant Quail in the Moore Laboratory of Zoology indicates that the degree of variation both within and between subspecies is greater than previously thought and that adjacent subspecies intergrade. On the basis of Friedmann's (1943) identification key our sample consisted of 11 males and 9 females of bensoni, 10 males of languens, 6 male and 13 female intergrades between bensoni and douglasii, 12 male intergrades between bensoni and languens, 12 males and 8 females of nominate douglasii, 5 males and 7 females of impedita, and 14 males and 6 females of teres. To assess dimorphism between the sexes in size, we ran a MANOVA test on all measured specimens, using sex as the independent variable. As expected, we found significant morphological differences $(p<0.01)$. We represented these differences graphically on a biplot of the first two principal components (Figure 3), which confirmed that male Elegant Quail are larger in all four measured morphological characteristics, even if the subspecies are pooled. The primary driver of PC1 is tail length, of PC2 wing chord (Figure 3). Tarsus contributed to PC3 and exposed culmen to PC4 (not shown). To prevent size dimorphism from drowning out any differences among subspecies, we based all analyses of subspecies on samples of one sex only. For both males and females, we compared the subspecies' morphology by three methods of subspecies identification: as previously written on the specimen's 


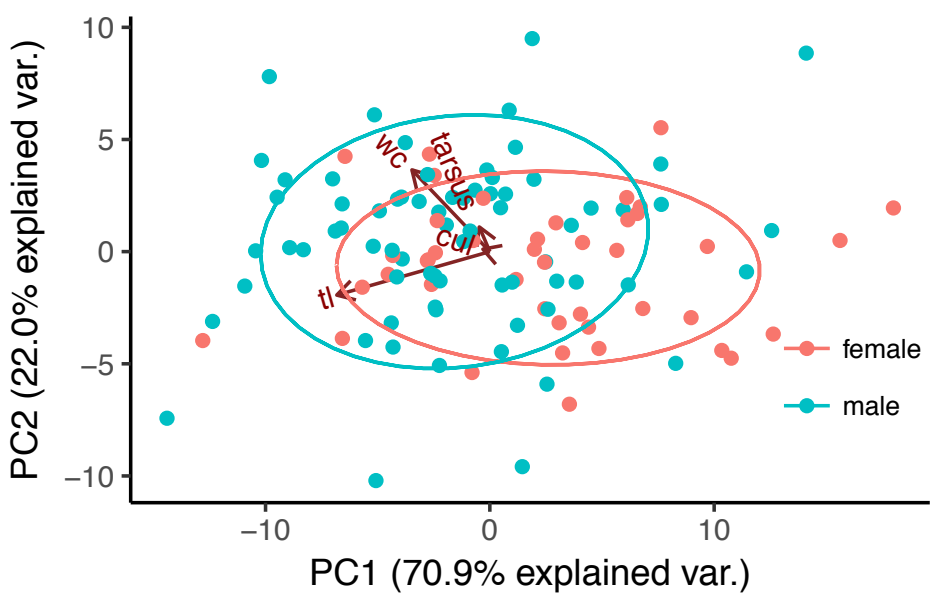

Figure 3. Biplot by sex of principal components derived from four size measurements of the Elegant Quail, all subspecies pooled. Red, females; blue, males. The separation between the two sexes in multivariate space graphically represents the significant differences between the sexes quantified by our MANOVA test for all four measured characteristics $(p<0.01)$. Males are generally larger, especially in tail length (tl) and wing chord (wc), as shown by the arrows indicating the direction of these variables.

tag, by the key, and by geography. We report the results of each of those tests in Table 1, which reveals that among the four variables measured, the subspecies differ significantly in tail length only. We then ran six PCAs, one for each combination of sex and method of subspecies identification, and generated biplots color-coded by subspecies (Figure 4). Each of these biplots shows the large overlap in the size variables, but as expected, the red arrow

Table 1 Evaluation of Variation of the Elegant Quail in Four Structural Variables by MANOVA

\begin{tabular}{|c|c|c|c|c|c|c|}
\hline \multirow{2}{*}{$\begin{array}{l}\text { Sex and } \\
\text { categorization } \\
\text { method }\end{array}$} & \multirow[b]{2}{*}{$\begin{array}{c}\text { Degrees of } \\
\text { freedom }\end{array}$} & \multicolumn{5}{|c|}{$P^{a}$} \\
\hline & & $\begin{array}{l}\text { Wing } \\
\text { chord }\end{array}$ & Tarsus & Culmen & Tail length & Summary ${ }^{b}$ \\
\hline \multicolumn{7}{|l|}{ Male } \\
\hline Geography & 3 & 0.56 & 0.76 & 0.73 & $0.01^{*}$ & 0.27 \\
\hline Tag & 3 & 0.67 & 0.81 & 0.53 & $0.001^{*}$ & 0.07 \\
\hline Key & 5 & 0.22 & 0.63 & 0.87 & $0.03^{*}$ & 0.43 \\
\hline \multicolumn{7}{|l|}{ Female } \\
\hline Geography & 3 & 0.21 & 0.4 & 0.34 & $0.003^{*}$ & $0.03^{*}$ \\
\hline Tag & 3 & 0.29 & 0.29 & 0.13 & $0.003^{*}$ & $0.01^{*}$ \\
\hline Key & 4 & 0.12 & 0.47 & 0.18 & $0.004^{*}$ & $0.007^{*}$ \\
\hline
\end{tabular}

${ }^{a}$ Values represent the probability of the null hypothesis of no differentiation in any of the five subspecies as defined by the specified method; values $<0.05$, flagged with an asterisk, mean that at least one of the subspecies differs significantly from the rest in this characteristic.

${ }^{b}$ Probability of no differentiation in all four variables pooled. 
representing tail length (tl) is the strongest factor discriminating between subspecies. After identifying tail length as a significant factor, we generated box plots of the tail length of each subspecies for each combination of sex and identification method (Figure 5). The most common trend across all the subspecies-identification methods is the tail tending to be longer in nominate douglasii than in all other subspecies. Nevertheless, agreement between identification methods was not absolute, even in this characteristic in which the difference was greatest.

\section{DISCUSSION}

Hybridization and intergradation in the quails of North America is well documented, affecting the species of the genus Callipepla as well as the bobwhites (Colinus spp.) and Mountain Quail (Oreortyx pictus) (Johnsgard 1971). Callipepla species often hybridize where their ranges overlap, as in the cases of the California (C. californica) and Gambel's (C. gambelii) quail - a common pairing (Gee 2004) —and of the Gambel's and Elegant quail. Elegant $\times$ Gambel's hybrids occur where the habitats of these species meet and grade into one another (Johnsgard 1971). Genetic studies (Zink and Blackwell 1998) suggest the relationship between the Elegant Quail and the Scaled, California, and Gambel's quails is close, implying the capacity of all species of Callipepla to produce viable hybrid offspring (Johnsgard 1971). Through the process of identifying specimens to subspecies by inspection of plumage characters, we found that many specimens (described in detail below) expressed characteristics of more than one subspecies. We interpret this as evidence of intergradation among the northern subspecies: douglasii, bensoni, and potentially languens. To outline potential zones of intergradation, we plotted the localities of the specimens in question. Nominate douglasii, bensoni, and languens may intergrade in southern Sonora, northern Sinaloa, and southwestern Chihuahua at the northern end of the range of douglasii, the southern end of the range of bensoni, and the southwestern edge of the range of languens.

\section{Plumage Patterns of Subspecies: Males (Figure 6)}

Typical males of $C$. $d$. douglasii (as exemplified by MLZ 19707; see Figure 2 for definitions of plumage patterns): Dark gray on the breast and rufous brown on the flanks and abdomen, the rufous being broken by white spots faintly ringed with slightly darker gray. Ridgway (1887) identified the predominantly white throat, forehead, crown, and nape with black spotting and streaking around the head as distinguishing nominate douglasii from the predominantly black-throated bensoni. The crest is bright rufous, and the back is uniformly slate gray. The undertail coverts are edged pale beige; the undersides of the rectrices are gray, paler than the breast. Rusty streaking does not extend onto the breast but is present as fainter spots on the sides. The white spots on the flanks, on a light rufous background, are large and not framed in a dusky outline. The rusty markings on the scapulars and nape are extensive and bright, interspersed with white streaks near the wings. Ridgway (1887) also identified the rump as being more olive than the bluegray rump of bensoni-noticeably greener in tone. The longest primaries 
extend past the longest secondaries, creating a visible wingtip. The remiges are uniformly pale brown.

Typical male of $C$. $d$. bensoni (as exemplified by MLZ 5653): Most notably darker on the throat than douglasii-the throat is predominantly black, and the breast is paler gray than in the males of douglasii. There is little or no darkening of this color on the lower abdomen. The white spots on the abdomen remain elliptical in shape and do not extend onto the breast. The undertail coverts and feathers of the ventral area are edged pale tawny, and the undersides of the rectrices are pale gray. The head is streaked white, as in douglasii, but the black streaking is bolder and more contrasting. White spots extend onto the flanks, and the wing coverts are uniformly light brown. Faint rusty spots from the back extend only up to the sides of the breast. The rusty markings on the back are present in same locations as on douglasii but are less extensive and slightly paler rufous. The back is uniformly slate gray, as is the rump, with no olive tone as in douglasii. The tips of the primaries extend noticeably beyond the secondaries.

Typical male of $C . d$. teres (as exemplified by MLZ 51359): The throat feathers are almost equally black and white, neither color obviously predominating over the other. The breast is uniform gray, and the white spots are restricted to the abdomen, with very few reaching the lower breast. The ventral area is rufous or rusty brown with contrasting white streaks, and the undertail coverts are unstreaked beige or edged pale tawny. The head is about equally streaked with black and white, not as dark as in typical bensoni or as pale as in typical douglasii. Rusty spotting extends from the sides of the nape along the sides and flanks, joining the rusty wash of the ventral area. The wing coverts and lower scapulars are brightly marked with rusty reddish and white streaks. The crest is a bright, pale cinnamon, paler than in either typical bensoni or typical douglasii. The back is slate gray and unmarked with no olive tinge. The longest primaries do not extend past the longest secondaries, so the wingtip is obscured. The rump and rectrices are also slate gray with no olive tinge.

Typical male of C. d. impedita (as exemplified by MLZ 21424): The throat is streaked black and white, rather than spotted as in the other subspecies. The auricular area is predominantly white with small black streaks, and from behind the crest down to the nape the crown and nape are rufous or rusty. The crest is pale cinnamon. The breast is dark gray with widely spaced white spots on the lower breast; they increase in size toward the abdomen. The ventral area tends to be a darker dusky brown with slight tinges of rufous on the sides. The undertail coverts are pale grayish brown edged with light brown. The wing coverts are light brown, and the scapulars are rusty with white streaks. The rusty color extends down onto the flanks and persists into the ventral area, meeting the dusky brown and white spots on the sides. The rusty markings with white streaks on the back are apparent but broken by olive-gray patches. The back is slate gray transitioning to olive gray on the lower back and rump. The rectrices are slate gray.

Typical male of $C$. $d$. languens (as exemplified by MLZ 17390): The most obvious distinguishing characteristic is the extensive rusty spotting across the gray breast-not present in the other subspecies but always visible in languens. The throat tends toward white like that of douglasii, and white 

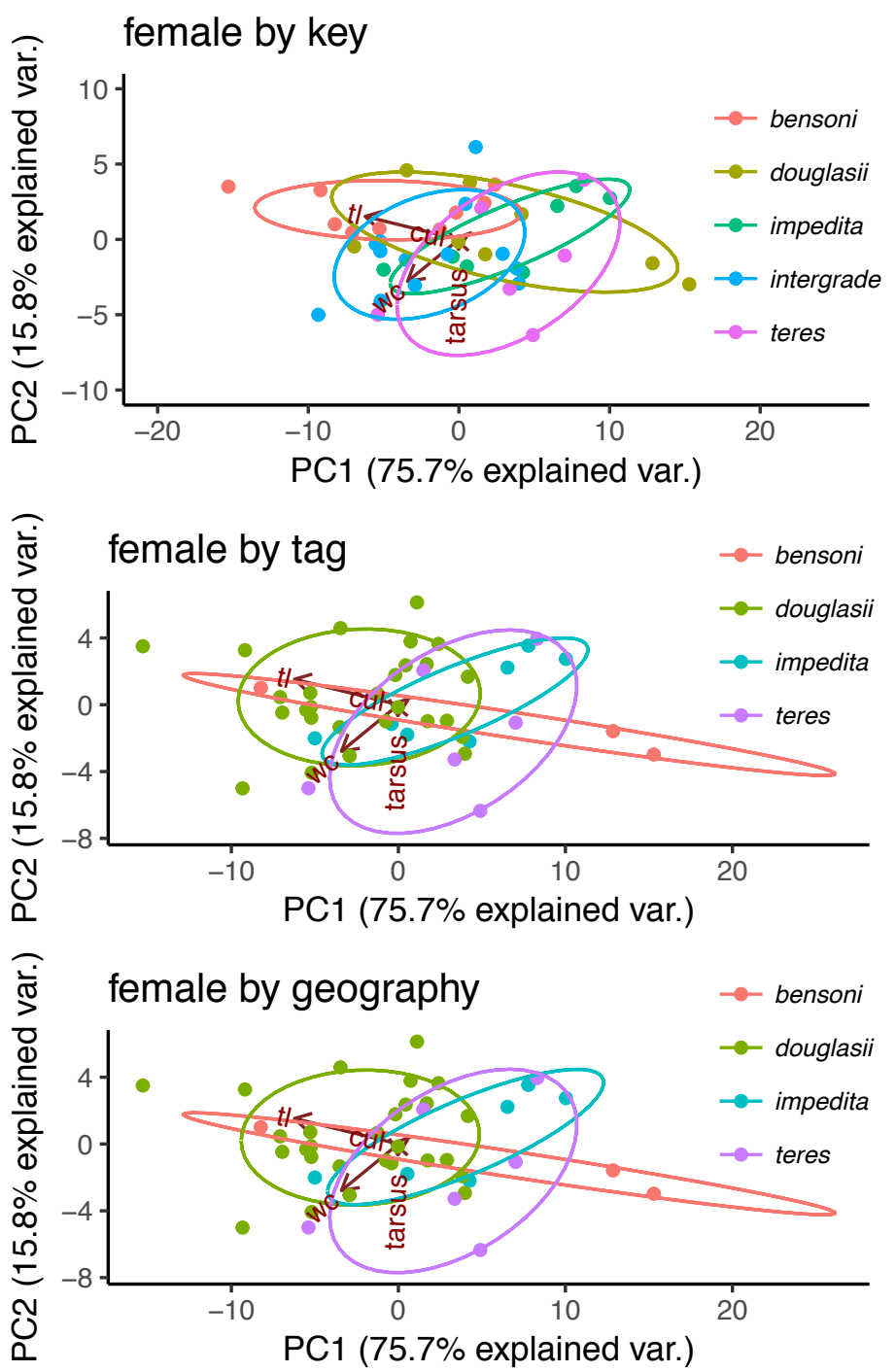

Figure 4. Biplots by sex of principal components derived from four size measurements of the Elegant Quail, color-coded according to subspecies as categorized by three methods. Key, subspecies as identified by plumage characters; tag, subspecies as previously identified on specimen label; geography, subspecies as defined geographically (see text). The red arrows represent the direction and magnitude of the effect of each of each of the four structures measured in explaining the species' variation in size. 


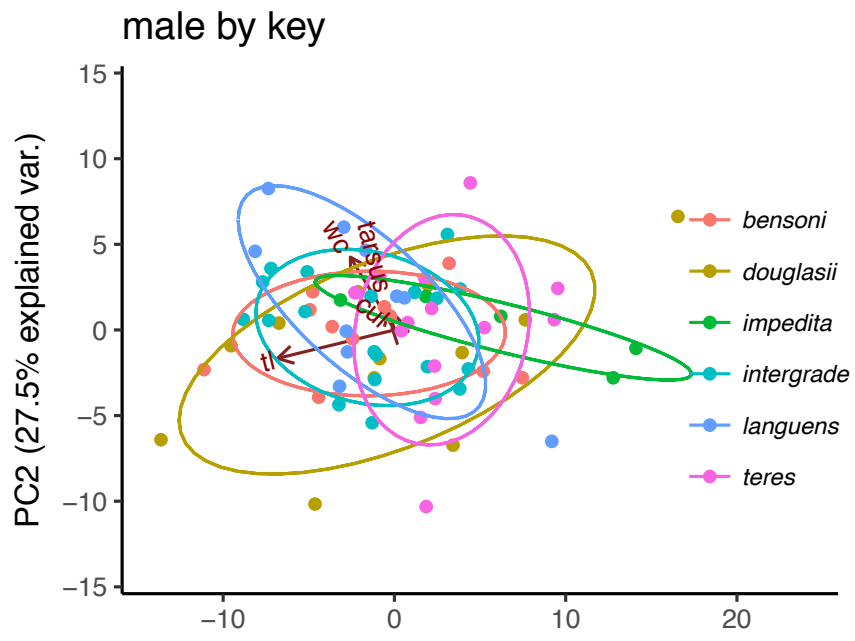

male by tag

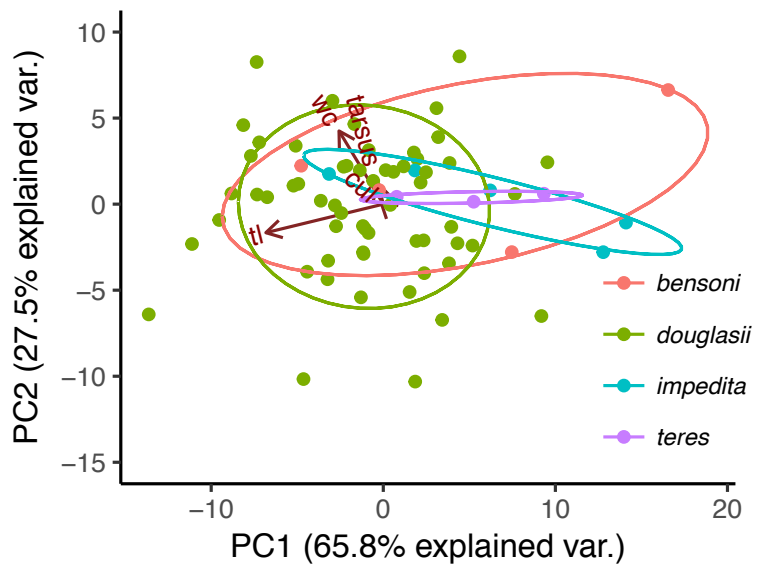

male by geography

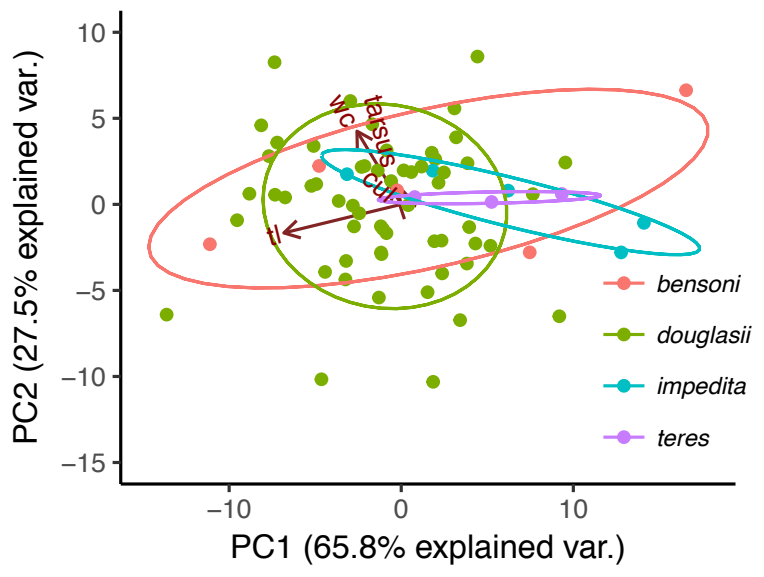



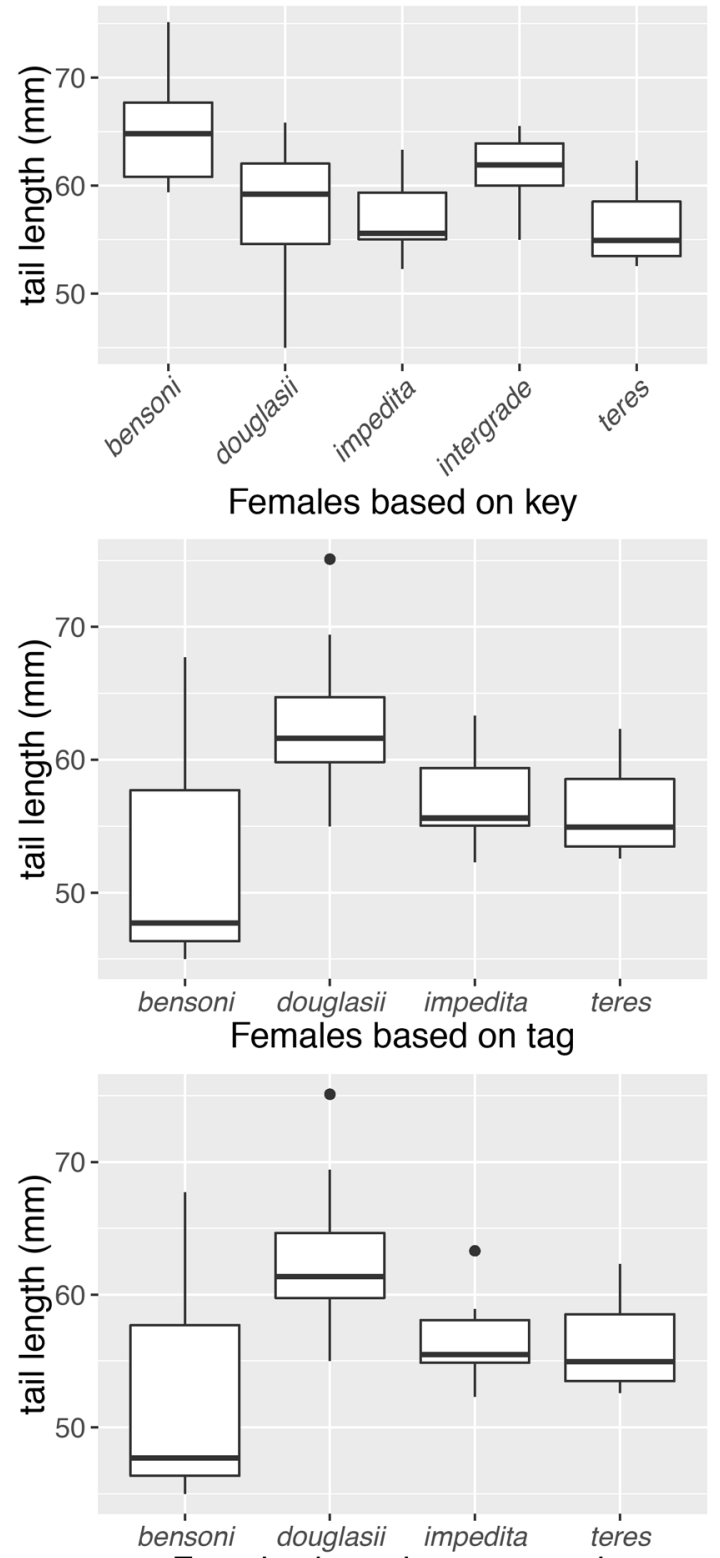

Females based on geography

Figure 5. Box-and-whisker plots representing the differences in tail length (in millimeters) between the subspecies of the Elegant Quail, as defined by three methods of categorizaton. Heavy horizontal bar, median; boxes, central quartiles of values; 

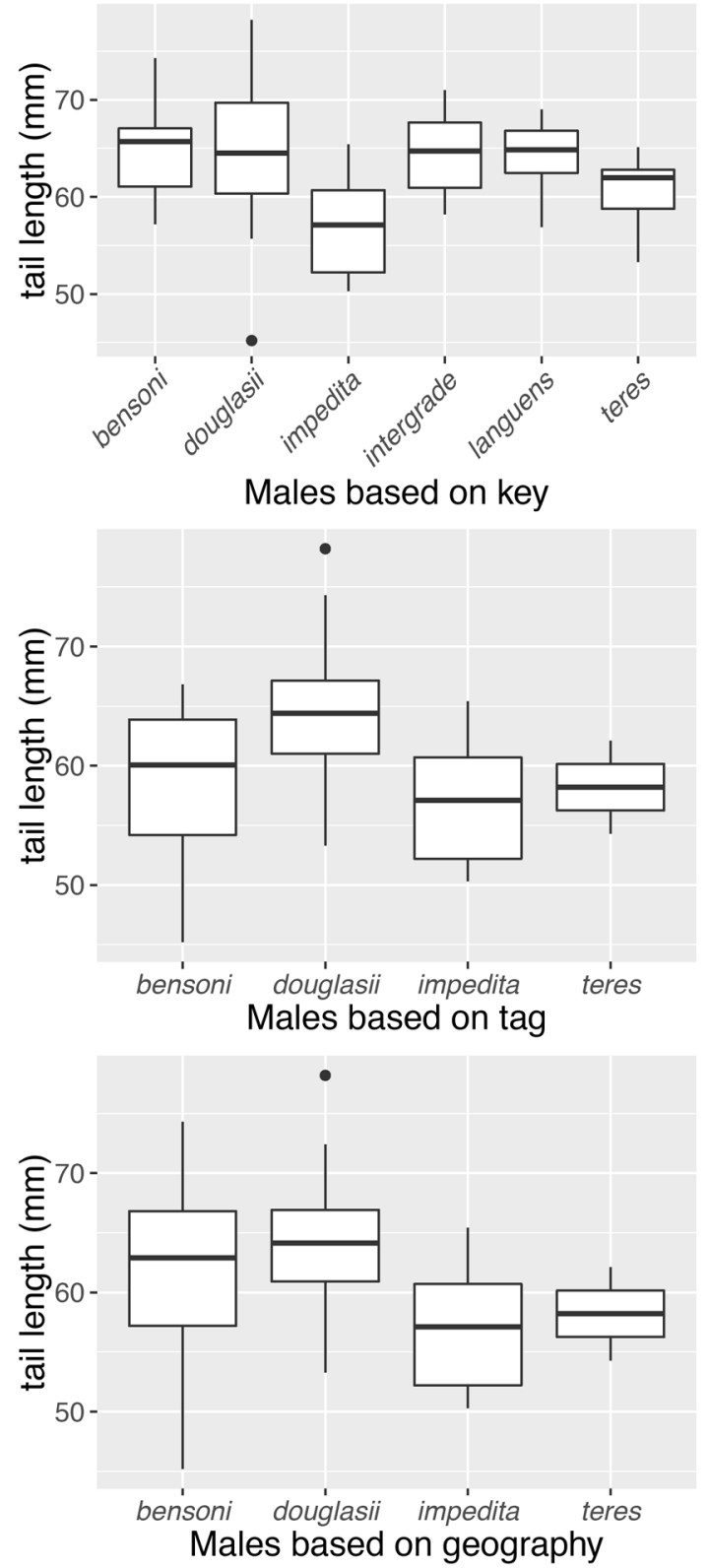

whiskers, maximum and minimum values except for dots representing outliers. Key, subspecies as identified by plumage characters; tag, subspecies as previously identified on specimen label; geography, subspecies as defined geographically (see text). 


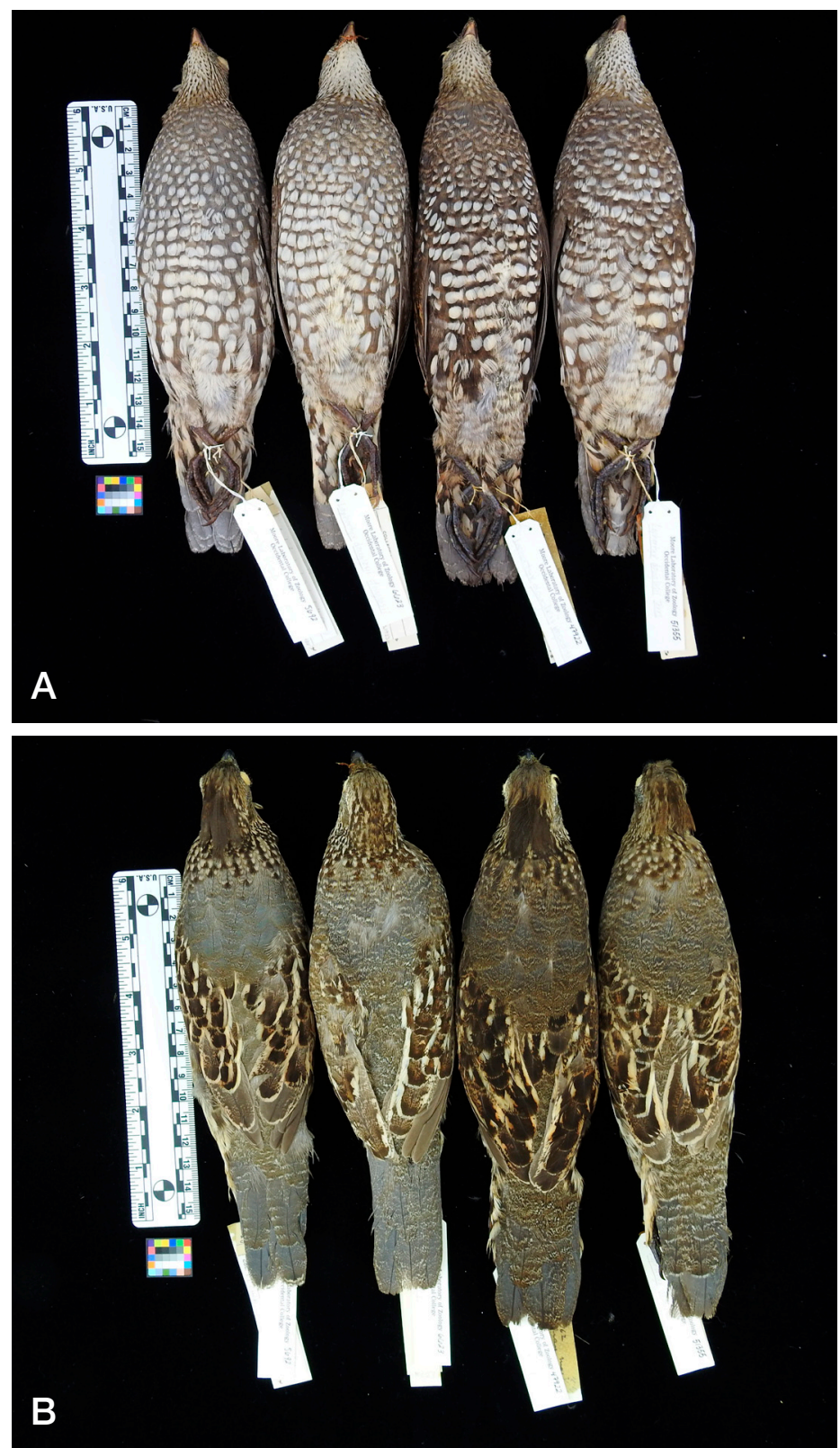

Figure 7. Females of four of the five subspecies of the Elegant Quail. A, underparts; B, upperparts. From left to right, bensoni (MLZ 5692), douglasii (MLZ 6623), impedita (MLZ 47922), teres (MLZ 51355). No female specimens of languens are known to us. 
spots cover the abdomen and lower breast. The ventral region and flanks rufous or reddish, and the undertail coverts are edged pale with faint barring. Along the sides from the top of the scapulars to the ends of the tail coverts the feathers are reddish or rusty with white streaks, as are the crown, nape, and sides of the throat. The crest is a bright reddish cinnamon. The sides of the breast and the upper back are dark gray. The lower back is slightly tinged olive. The rectrices are slate gray.

\section{Plumage Patterns of Subspecies: Females (Figure 7)}

Typical female of $C$. $d$. douglasii (as exemplified by MLZ 6623): The whitish throat is faintly marked with small brown spots. The drab breast is covered in white spots that become denser and more rectangular in shape posteriorly. The crown and forehead are streaked with dusky brown on tawny. The crest is medium brown but distinctly barred with lighter tawny (Ridgway 1887). The white of the throat contrasts with dark blackish-brown or dusky streaking extending to the sides of the throat. The tawny of the head and nape is thickly streaked with light brown; the back is olive gray with faint transverse tawny barring. The scapulars and wing coverts are dark brown fringed with light tawny. The abdomen is patterned with rectangular white spots surrounded by dark olive-brown; the undertail coverts are beige. The uppertail coverts and rectrices are olive gray, slightly paler than the back, and similarly marked transversely with lighter brown.

Typical female of $C$. $d$. bensoni (as exemplified by MLZ 5692): The best distinguishing character is crest color-the adult female has a uniformly dusky or blackish brown crest with no barring as in typical douglasii. The throat is whitish but averages more obviously streaked with brown. The breast is more tawny in color than drab, and the profuse whitish spots on the breast and abdomen remain mostly elliptical; they extend up the sides of the breast as narrower horizontal bars. The gray of the bases of the abdominal feathers darkens slightly to darker olive toward the midline of the belly. The whitish of the underparts, including the ventral area and undertail coverts, is tinged with brown or tawny. The scapulars and wing coverts are dusky brown edged with bright tawny, as are feathers of the flanks. The forehead, crown, and nape are pale tawny but thickly barred or spotted with dark dusky brown. This pattern ends at the back, which, according to Ridgway (1887), is on average less marked with pale brown than is douglasii. The rectrices are uniformly slate gray. The longest primaries extend slightly beyond the longest secondaries.

Typical female of $C$. $d$. teres (as exemplified by MLZ 51355): The breast is drab brown or grayish, similar to that of douglasii, but the white spots are less dense and remain elliptical in shape throughout the abdomen. The crest is light brown barred with brown. The ventral area is slightly darker than the more anterior section of the abdomen and breast. The throat is pale whitish with little streaking or marking. The undertail coverts are light tawny or beige edged and faintly barred with gray or light brown. From below, the rectrices are uniform gray. The sides of the breast are grayer and more finely streaked than in typical bensoni or typical douglasii. The scapulars and wing coverts are lighter grayish brown edged with pale tawny. The female of $C$. $d$. teres 
is generally more thinly streaked on the crown and nape and more thickly barred on the back, uppertail coverts, and rectrices than in the other three subspecies for which females were available.

Typical female of $C$. $d$. impedita (as exemplified by MLZ 47922): The throat is mostly white with some brown streaking; the breast is fawn-colored transitioning to dark dusky brown on the abdomen. The crest is a uniform dark brown with no barring. The white spots on the abdomen are numerous, large, and faintly ringed in blackish; they decrease in size toward the breast, where they become barring. The ventral region and undertail coverts are pale tawny edged with faint dusky gray barring. The sides of the breast are gray with faint tawny barring. The wing coverts and the scapulars are bright tawny marked with dusky. The flanks are dark dusky with white and tawny spotting. The nape is light brown with darker streaking, and the back and rump are slate gray with faint dusky and tawny barring. The rectrices are mostly uniform gray with some barring. The rump is slightly olive, and the longest primaries very slightly exceed the longest secondaries in length.

Intergrades

C. $d$. bensoni $\times$ C. $d$. douglasii: MLZ 5658, female collected at Guirocoba, southern Sonora $\left(26.903^{\circ} \mathrm{N}, 108.695^{\circ} \mathrm{W}\right)$, and 5660 , female collected at Camoa, southern Sonora $\left(27.225^{\circ} \mathrm{N}, 109.260^{\circ} \mathrm{W}\right)$ : These two specimens have the throat whitish with obvious brown spotting, as is typical of female bensoni, but a dark brown crest barred with tawny, closer to typical female douglasii. The degree of throat spotting within each subspecies varies, but in these specimens it appears to be closer to the thick spotting of bensoni than to the sparse spotting of douglasii.

C. $d$. bensoni $\times$ C. $d$. douglasii: MLZ 5661, female collected at Camoa, southern Sonora. This specimen has a darkly spotted throat but a barred brownish crest, characters associated with bensoni and douglasii, respectively. Barring is present on the back and rump as well as on the uppertail coverts and the rectrices, consistent with douglasii. Dusky markings on the scapulars and nape are as dark and extensive as on the back, consistent with bensoni.

C. $d$. bensoni $\times$ C. $d$. languens: MLZ 6616, 6625, and 6653, males collected at Yecorato, northern Sinaloa $\left(26.430^{\circ} \mathrm{N}, 108.218^{\circ} \mathrm{W}\right), 6633$, male collected at Baromico, southern Sonora $\left(27.025^{\circ} \mathrm{N}, 108.579^{\circ} \mathrm{W}\right)$, and 6635 , male collected at Ahome, southern Sonora $\left(25.920^{\circ} \mathrm{N}, 109.173^{\circ}\right.$ $\mathrm{W})$. These five specimens have the mostly black throat characteristic of bensoni, not the white throat with black spots found in languens. They also have considerable red spotting on the breast, a character exclusive to languens and not found in bensoni.

C. $d$. bensoni $\times$ C. $d$. douglasii: MLZ 6650, male collected at Ahome, southern Sonora. This specimen features both the predominantly white throat typical of douglasii and the pale smoke-gray breast typical of bensoni. The breast is noticeably paler than in typical douglasii.

Our results demonstrate the high degree of variability in morphology within all five subspecies of the Elegant Quail, which was previously unknown. There is extensive overlap between subspecies in all four structures 
measured, suggesting high variability among individuals, and low differentiation in size between the subspecies (Figure 4). Even in the mensural characteristic in which the difference is greatest (tail length), changing the method used to assign an individual to subspecies can give conflicting results (Figure 5). Thus variation in plumage color and pattern, not size, are key for delineating subspecies in the Elegant Quail. Future research should focus on quantifying the differences between the subspecies in their complex plumage patterns and determining the range boundaries of the various subspecies.

\section{ACKNOWLEDGMENTS}

We thank David E. Quady, Daniel D. Gibson, and Steven C. Rottenborn of Western Field Ornithologists for facilitating the presentation of this research at WFO's 41st annual conference in Fortuna, California, and thank the attendees at the conference for providing discussion and feedback on the presentation. We thank reviewers M. Ralph Browning, Maria del Rocio Cabrera, and Jennifer Gee for their excellent comments improving the manuscript. We thank John McCormack of the Moore Laboratory of Zoology for access to resources and specimens used in the study. We thank editor Philip Unitt for significantly improving the manuscript.

\section{LITERATURE CITED}

Dickinson, E. C., and Remsen, J. V. Jr. (eds.). 2013. The Howard and Moore Complete Checklist of the Birds of the World, 4th ed., vol. 1: Non-passerines. Aves Press, Eastbourne, England.

Friedmann, H. 1943. Critical notes on the avian genus Lophortyx. J. Washington Acad. Sci. 33:369-371.

Friedmann, H. 1946. The birds of North and Middle America. Bull. U.S. Natl. Mus. 50, part X.

Gee, J. M. 2004. Gene flow across a climatic barrier between hybridizing avian species, California and Gambel's quail (Callipepla californica and C. gambelii). Evolution 58:1108-1121; doi 10.1111/j.0014-3820.2004.tb00444.x.

Johnsgard, P. 1971. Experimental hybridization of the New World quail (Odontophorinae). Auk 88:264-275; doi 10.2307/4083879.

Smithe, F. B. 1975. The Naturalist's Color Guide. Am. Mus. Nat. Hist., New York. Ridgway, R. 1887. A Manual of North American Birds. J. B. Lippincott, Philadelphia.

Zink, R. M., and Blackwell, R. C. 1998. Molecular systematics of the Scaled Quail complex (genus Callipepla). Auk 115:394-403; doi 10.2307/4089198.

Accepted 16 July 2017 